\title{
Differences in HPV infection and HPV-related lesions between the cervix and anus in hiv-positive women
}

\author{
Diferenças na infecção por HPV e lesões HPV-relacionadas entre colo uterino e ânus \\ em mulheres hiv positivas
}

\author{
Marcos Paulo Cardoso Marques ${ }^{1}$, Amanda Chaves Pinto ${ }^{2}$, Leila Cristina Soares ${ }^{3 *}$, Jacyara Maria Brito \\ Macedo ${ }^{4}$, Debora Fontenelle dos Santos ${ }^{5}$, Marco Aurelio Pinho Oliveira ${ }^{3}$
}

\author{
${ }^{1}$ Collaborating Professor, University of Grande Rio; ${ }^{2}$ Advanced Technician, Rio de Janeiro State University, \\ Department of Biochemistry; ${ }^{3}$ Adjunct Professor, Rio de Janeiro State University, Gynecology Department; ${ }^{4}$ Associate \\ Professor, Rio de Janeiro State University, Department of Biochemistry; ${ }^{5}$ Health Care Coordination, CAM
}

\begin{abstract}
Introduction: the prevalence of cervical and anal human papillomavirus (HPV) infection in women infected with human immunodeficiency virus (HIV) is high. However, little is known about the differences in the susceptibility of these infections and related lesions. The aim of this study was to describe the association between the prevalence of cervical and anal HPV infection and HPV-related lesions in HIV-positive women. Methods: this study included 88 HIV-positive women attending an outpatient clinic in a university hospital. Ectocervical, endocervical, and anal samples were collected for colpocytology and anal cytology. A polymerase chain reaction-based technique was used to detect HPV deoxyribonucleic acid in endocervical and anal swab samples. Results: the cervical and anal HPV positivity rates were $35.21 \%$ and $78.8 \%$, respectively. The presence of HPV-related lesions on colpocytology was associated with anal HPV positivity $(P=0.027)$. The ratio between cervical HPV infection and cervical HPV-related lesions was 2.5. The ratio between anal HPV infection and anal HPV-related lesions was 4.3. Overall, 30\% had concomitant HPV DNA in the cervix and anus. Conclusion: there are differences in the susceptibility of infections and related lesions between the cervix and anus. Despite a higher incidence of anal HPV, the progression to HPV-related lesion does not occur via the same manner in the cervix and anus. Moreover, cervical HPV-related lesions in HIV-positive women may serve as a cue for anal preventive strategies, and further investigations in these women may be useful.
\end{abstract}

Keywords: Anus Neoplasms. Cervical Intraepithelial Neoplasia. Human Immunodeficiency Virus. Human Papillomavirus

\begin{abstract}
Resumo
Introdução: as infecções cervicais e anais pelo papilomavírus humano (HPV) em mulheres infectadas com o vírus da imunodeficiência humana (HIV) são muito prevalentes. Entretanto, pouco se sabe sobre as diferenças na suscetibilidade entre essas infecções e as lesões HPV-relacionadas. Objetivo: descrever a associação entre as prevalências de infecção cervical e anal pelo HPV e lesões relacionadas em mulheres HIV-positivas. Metodologia: este estudo incluiu 88 mulheres HIV-positivas atendidas em ambulatório de hospital universitário. Amostras ectocervicais, endocervicais e anais foram coletadas para colpocitologia e citologia anal. Uma técnica baseada na reação em cadeia da polimerase foi usada para detectar o ácido desoxirribonucléico (DNA) do HPV em amostras de swabs endocervical e anal. Resultado: as taxas de positividade do HPV cervical e anal foram de $35,21 \%$ e $78,8 \%$, respectivamente. As lesões relacionadas ao HPV na colpocitologia foram associadas à positividade anal para o HPV $(P=0,027)$. A proporção entre infecção cervical por HPV e lesões cervicais relacionadas foi de 2,5. A proporção entre a infecção anal por HPV e as lesões anais relacionadas foi de $4,3.30 \%$ tinham DNA-HPV concomitante no colo do útero e ânus. Conclusão: existem diferenças na suscetibilidade de infecções e de lesões relacionadas entre o colo e o ânus. Apesar de maior incidência de HPV anal, a progressão para lesões relacionadas não ocorre da mesma forma no colo e no ânus. Além disso, lesões cervicais relacionadas ao HPV em mulheres HIV positivas podem servir como pista para estratégias preventivas anais. Investigações adicionais podem ser úteis.
\end{abstract}

Palavras-chave: Neoplasias do Ânus. Neoplasia Intraepitelial Cervical. Vírus da Imunodeficiência Humana. Papilomavírus Humano.

\section{INTRODUCTION}

Human immunodeficiency virus (HIV)-related immunodeficiency has an negative effect on the natural lifecycle of human papillomavirus (HPV) and is associated with an increased risk of the onset and tenacity of HPV infection as well as the development of HPV-related lesions (CLEMENTE et al., 2017).

Corresponding/Correspondente:*Leila Cristina Soares - End: Av 28 de setembro, 75 - 50 andar Vila Isabel - Rio de Janeiro - Brasil - CEP: 20551031 - Tel: 55 (21) 2868-8269 - E-mail: Ics1507@yahoo.com.br
At present, anal cancer is among the most common non-acquired immunodeficiency syndrome (AIDS)-defining tumors in patients with HIV infection, and invasive cervical cancer has been identified as a defining diagnostic factor for AIDS since 1993 (FRAZIER et al., 2016; HIDALGO-TENORIO et al., 2017). Although relatively uncommon in the general population, immunocompromized patients are at a higher risk of anal cancer. Moreover, there is no evidence of a decrease in the incidence of anal cancer following the introduction of an effective antiretroviral therapy (ART) (MACHALEK et al., 2012). 
Compared with the current knowledge about the associations of cervical HPV infection and cervical cytohistopathological results with cervical cancer and precursor lesions, little is known about the prognostic benefits of anal screening to predict the risk of anal cancer, given that the incidence of new cases of anal squamous carcinoma has continued to increase by 2-3\% annually over the past decade (DAVIS; ORANGIO, 2018; LIN et al., 2019).

The aim of the present study was to identify the association between the prevalence of cervical and anal HPV infections and the development of HPV-related lesions in HIV-positive women.

\section{METHODOLOGY}

This cross-sectional study included HIV-positive women attending an outpatient clinic in Pedro Ernesto Universitary Hospital, Rio de Janeiro, Brazil, from October 2017 to January 2019. The study protocol was approved by the Local Ethics Committee on August 12, 2016 (CAAE number 58111916.3.0000.5259) and conducted in accordance with the tenets of the Declaration of Helsinki.

Sample size calculation was based on the preliminary supposition that the occurrence of HPV infection in cervix was approximately $30 \%$, and in anus was $60 \%$ in HIV women. With an alpha error type of $5 \%$ and a power of $80 \%$ of detecting a prevalence difference of $25 \%$, the program suggested 42 cases in each group.

Participants with a prior hysterectomy or who had not experienced sexual intercourse at the time of enrollment in the study were excluded. A total of 88 women were included. All the participants signed an informed consent form prior to inclusion in the study.

Following collection of demographic data, each woman underwent anamnesis and a gynecological examination, during which ectocervical and endocervical samples were collected using a wooden Ayres spatula and a cytobrush, respectively. Anal cytological samples were collected by making gentle rotation movements with a cytobrush at a depth of approximately $4 \mathrm{~cm}$, while avoiding contact with any external lesion. The slides were prepared by the conventional method, fixed, and stored in alcohol at $90^{\circ} \mathrm{C}$ until further analysis. The cytological findings were interpreted based on the 2014 Bethesda System for Reporting Cervical Cytology, in accordance with the Brazilian Unic Health System criteria. Samples classified as atypical squamous cells of undetermined significance (ASC-US), atypical glandular cells, atypical squamous cells that do not exclude high-grade squamous intraepithelial lesions (ASC-H), low-grade squamous intraepithelial lesion (LSIL), high-grade squamous intraepithelial lesion (HSIL), and invasive carcinoma were considered to be positive for HPV-related lesions.

Total deoxyribonucleic acid (DNA) was isolated from cervical swabs, as described previously, whereas that from anal swabs was extracted using the Invisorb ${ }^{\circledR}$ Spin Tissue Mini Kit (Invitek Molecular GmbH, Berlin, Germany), in ac- cordance with the manufacturer's instructions. HPV DNA in biological samples was detected using a polymerase chain reaction (PCR)-based technique, as described by Klumb et al. (2010). Samples positive for human $\beta$-globin expression (primers set PCO3/PCO4) were subjected to viral DNA amplification using total DNA as templates and the following two primers sets separately: MY09/MY11-MYPCR and GPO5+/GPO6+-GP-PCR (HUSMAN et al., 1995; KLUMB et al., 2010; MANOS et al. 1989). Nested PCR was also performed using the two sets of specific primers with the MY-PCR amplicons as templates. Cervical samples were defined as HPV DNA-positive when at least one of the amplification reactions (MY-PCR, GP-PCR, or nested $P C R$ ) gave a positive result.

All statistical analyses were performed using IBM SPSS Statistics for Windows, version 22.0. (IBM Corporation, Armonk, NYUSA). Data were compared using the Fisher's exact test or chi-square test, as appropriate. A probability $(P)$ value of $\leq 0.05$ was considered statistically significant.

\section{RESULTS}

Of the 88 women included in this study, a total of 71 (80.7\%) with cervical material and 59 (67.0\%) with anal material deemed adequate for PCR analysis (globin gene as internal control) were included for analysis. The predominant self-reported ethnic groups were African American (41, 46.6\%), followed by Caucasian (27, 30.7\%) and others (20, 22.7\%). Most women reported low family incomes of up to the equivalent of $\$ 243.71$ (minimum wage in Brazil at the time of the study).

Overall, 49 (56.3\%) women were past or present smokers. Cervical and anal samples deemed adequate for analysis of HPV DNA were collected from 71 (81.0\%) and 59 (67.0\%) women, respectively. Samples from 50 (56.8\%) women were adequate for both.

Adequate cervical samples from 9 (10.2\%) women and anal samples from 7 (8.0\%) women had detectable viral loads and/or CD4 ${ }^{+} T$-cell counts of $<200$ (5 positive for cervical HPV). Of the 71 cervical HPV samples deemed adequate, 25 (35.21\%) were positive for HPV DNA. There were no differences in terms of sociodemographic characteristics and HPV DNA positivity within age groups $(P=$ $0.429)$, ethnicities $(P=0.426)$, income levels $(P=0.590)$, pregnancy $(P=0.121)$, parity $(P=0.102)$, or smoking history $(P=0.451)$.

Colpocytology with HPV-related diseases was associated with positive cervical HPV [odds ratio (OR) 5.317; 95\% confidence interval (CI): 1.572-19.83; $P=0.006$ ]. Although not significant, positive cervical HPV tended to be associated with the presence of anal HPV-related lesions (OR 3.777; 95\% Cl 0.934-19.83; $P=0.064$ ). No significant differences were noted in cervical HPV frequency and sexual activity $(P=0.126)$, unprotected receptive anal intercourse $(P=0.930)$, exchange of partners within the last 3 months $(P=0.097)$, and anal HPV $(P=0.171)$ (Table 1$)$. 
Table 1 - Sociodemographic and clinical characteristics stratified by diagnosis of cervical HPV and associations

\begin{tabular}{|c|c|c|c|c|c|}
\hline & Negative & & Positive & & P-value \\
\hline & $n$ & $\%$ & $n$ & $\%$ & \\
\hline \multicolumn{6}{|l|}{ Age (years) } \\
\hline$\leq 50$ & 31 & 67.4 & 20 & 80 & $0.276^{* *}$ \\
\hline$>50$ & 15 & 32.6 & 5 & 20 & \\
\hline \multicolumn{6}{|l|}{ Ethnicity } \\
\hline Caucasian & 13 & 28.3 & 5 & 20.0 & $0.426^{* *}$ \\
\hline African American & 22 & 47.8 & 16 & 64.0 & \\
\hline Other & 11 & 23.9 & 4 & 16.0 & \\
\hline \multicolumn{6}{|l|}{ Family income } \\
\hline \multicolumn{6}{|l|}{ (Brazilian MW $=\$ 243.71$ ) } \\
\hline$>1 \mathrm{MW}$ & 25 & 54.3 & 11 & 44.0 & $0.590 * *$ \\
\hline $1-2 M W$ & 10 & 21.7 & 10 & 40.0 & \\
\hline$>2-3 M W$ & 6 & 13.0 & 2 & 8.0 & \\
\hline$>4-5 M W$ & 3 & 6.5 & 1 & 4.0 & \\
\hline$>5 \mathrm{MW}$ & 2 & 4.3 & 1 & 4.0 & \\
\hline \multicolumn{6}{|l|}{ Pregnancies } \\
\hline 0 & 0 & 0.0 & 2 & 8.0 & $0.121 *$ \\
\hline$\geq 1$ & 46 & 100 & 23 & 92.0 & \\
\hline \multicolumn{6}{|l|}{ Parity } \\
\hline 0 & 0 & 0.0 & 4 & 16.0 & $0.102 *$ \\
\hline$\geq 1$ & 46 & 56.5 & 21 & 56.0 & \\
\hline \multicolumn{6}{|l|}{ Smoking } \\
\hline Never & 22 & 47.8 & 10 & 40 & $0.451^{* *}$ \\
\hline Ever or current & 24 & 52.2 & 15 & 60 & \\
\hline Detectable viral load and/or CD4+T cells $<200$ & & & & & $0.557^{*}$ \\
\hline Yes & 4 & 12.68 & 5 & 20 & $0.710^{*}$ \\
\hline No & 20 & 87.32 & 42 & 80 & \\
\hline \multicolumn{6}{|l|}{ Colpocytology } \\
\hline Benign cellular changes & 41 & 89.1 & 15 & 60.0 & $0.006^{* *}$ \\
\hline HPV-related lesions & 5 & 10.9 & 10 & 40.0 & \\
\hline \multicolumn{6}{|l|}{ Anal cytology } \\
\hline Benign cellular changes & 41 & 89.1 & 17 & 68.0 & $0.064 *$ \\
\hline HPV-related lesions & 5 & 10.9 & 8 & 32.0 & \\
\hline \multicolumn{6}{|l|}{ Anal HPV } \\
\hline Negative & 12 & 36.4 & 3 & 17.6 & $0.171^{* *}$ \\
\hline Positive & 21 & 63.6 & 14 & 82.4 & \\
\hline \multicolumn{6}{|l|}{ Sexual activity (intercourse) } \\
\hline Within last year & 33 & 71.1 & 22 & 88.0 & $0.126^{* *}$ \\
\hline$>1$ year & 13 & 28.9 & 3 & 12.0 & \\
\hline \multicolumn{6}{|l|}{ Unprotected anal intercourse recipient } \\
\hline No & 36 & 78.3 & 20 & 80 & $0.882^{* *}$ \\
\hline Yes & 10 & 21.7 & 5 & 20 & \\
\hline \multicolumn{6}{|l|}{ Change of partners within the last 3 months } \\
\hline No & 45 & 97.8 & 21 & 84.0 & $0.097^{*}$ \\
\hline Yes & 1 & 2.2 & 4 & 16.0 & \\
\hline
\end{tabular}

$M W=$ minimum wage; $H P V=$ Human papillomavirus; $A R T=$ antiretroviral therapy

*Fisher test; ** chi-square test

Source: Research data

Of the 59 women with anal HPV samples deemed adequate for analysis, 43 (72.88\%) were also positive for anal HPV DNA. There were no differences in sociodemographic characteristics and HPV DNA positivity within age groups $(P=0.721)$, ethnicities $(P=0.274)$, family income levels $(P=$ $0.352)$, smoking history $(P=0.230)$, pregnancy $(P=0.528)$, or parity $(P=0.379)$. Regarding clinical characteristics, there were no significant differences between sexual activity $(P=0.998)$, cervical HPV $(P=0.171)$, change of partners within the last 3 months $(P=0.998)$, and anal cytology ( $P$ $=0.259)$. Only $18.6 \%$ of the women positive for anal HPV reported unprotected receptive anal intercourse, although 
there was no correlation with anal HPV frequency $(P=\quad(P=0.027)$. The anal HPV positive rate in this group was 0.713). The presence of HPV-related lesions, as detected $100 \%$. As a rule, if in a $2 \times 2$ contingency table the count by colpocytology, was associated with anal HPV positivity in any cell is zero, the odds ratio is undefined (Table 2).

Table 2- Sociodemographic and clinical characteristics stratified by diagnosis of anal HPV and associations

\begin{tabular}{|c|c|c|c|c|c|}
\hline & Negative & $\%$ & Positive & $\%$ & P-value \\
\hline \multicolumn{6}{|l|}{ Age (years) } \\
\hline$\leq 50$ & 13 & 81.2 & 31 & 72.1 & $0.721^{*}$ \\
\hline$>50$ & 3 & 18.8 & 12 & 27.9 & \\
\hline \multicolumn{6}{|l|}{ Ethnicity } \\
\hline Caucasian & 3 & 18.8 & 14 & 32.6 & $0.274^{* *}$ \\
\hline African American & 7 & 43.8 & 21 & 48.8 & \\
\hline Other & 6 & 37.5 & 8 & 18.6 & \\
\hline \multicolumn{6}{|l|}{ Family income } \\
\hline \multicolumn{6}{|l|}{ (Brazilian MW = \$243.71) } \\
\hline$>1 \mathrm{MW}$ & 10 & 62.5 & 22 & 51.2 & $0.352 * *$ \\
\hline $1-2 \mathrm{MW}$ & 3 & 18.8 & 11 & 25.6 & \\
\hline$>2-3 \mathrm{MW}$ & 1 & 6.3 & 8 & 18.6 & \\
\hline$>4-5 \mathrm{MW}$ & 0 & 0.0 & 1 & 2.3 & \\
\hline$>5 \mathrm{MW}$ & 2 & 12.5 & 1 & 2.3 & \\
\hline \multicolumn{6}{|l|}{ Pregnancies } \\
\hline 0 & 0 & 0.0 & 2 & 4.7 & $0.528 * *$ \\
\hline$\geq 1$ & 16 & 100 & 41 & 65.3 & \\
\hline \multicolumn{6}{|l|}{ Parity } \\
\hline 0 & 0 & 0 & 3 & 7.0 & $0.379 * *$ \\
\hline$\geq 1$ & 16 & 100 & 40 & 93 & \\
\hline \multicolumn{6}{|l|}{ Smoking } \\
\hline Never & 10 & 62.5 & 19 & 44.2 & $0.230 * *$ \\
\hline Ever or current & 6 & 37.5 & 24 & 55.8 & \\
\hline \multicolumn{6}{|c|}{ Detectable viral load and/or CD4+ T cells $<200$} \\
\hline Yes & 1 & 11.9 & 6 & 13.1 & $0.760^{*}$ \\
\hline No & 15 & 88.1 & 37 & 85.9 & \\
\hline \multicolumn{6}{|l|}{ Colpocytology } \\
\hline Benign cellular changes & 16 & 100.0 & 31 & 72.1 & $0.027^{*}$ \\
\hline HPV-related lesions & 0 & 0.0 & 12 & 27.9 & \\
\hline \multicolumn{6}{|l|}{ Anal cytology } \\
\hline Benign cellular changes & 15 & 93.8 & 33 & 76.7 & $0.259 *$ \\
\hline HPV-related lesions & 1 & 6.3 & 10 & 23.3 & \\
\hline \multicolumn{6}{|l|}{ Cervical HPV } \\
\hline Negative & 12 & 80.0 & 21 & 60.0 & $0.171^{* *}$ \\
\hline Positive & 3 & 20.0 & 14 & 40.0 & \\
\hline \multicolumn{6}{|l|}{ Sexual activity (intercourse) } \\
\hline Within last year & 13 & 81.3 & 34 & 79.1 & $0.998^{*}$ \\
\hline$>1$ year & 3 & 18.8 & 9 & 20.9 & \\
\hline \multicolumn{6}{|c|}{ Unprotected anal intercourse recipient } \\
\hline No & 14 & 87.5 & 35 & 81.4 & $0.713^{*}$ \\
\hline Yes & 2 & 12.5 & 8 & 18.6 & \\
\hline \multicolumn{6}{|c|}{ Exchanged partners within the last 3 months } \\
\hline No & 15 & 93.8 & 39 & 90.7 & $0.998^{*}$ \\
\hline Yes & 1 & 6.3 & 4 & 9.3 & \\
\hline
\end{tabular}

$M W=$ minimum wage; $H P V=$ Human papillomavirus; $A R T=$ antiretroviral therapy

*Fisher test; ** chi-square test

Source: Research data

According to cytological results, 15 (21.1\%) women had HPV-related cervical lesions and 11 (18.6\%) had HPV-related anal lesions. Of the HPV-related cervical le- sions, five were ASC-US, two ASC-H, three LSIL, four HSIL, and one invasive carcinoma. Of the HPV-related anal lesions, eight were ASC-US, one ASC-H, and two LSIL. Of 
the 25 women positive for cervical HPV infection, 10 had cervical HPV-related lesions (ratio of 2.5). Of the 43 women positive for anal HPV infection, 10 had anal HPV-related lesions (ratio of 4.3).

Among the 50 women with adequate cervical and anal samples, 15 (30\%) had concomitant HPV infection of the cervix and anus, 6 (12\%) had cervical HPV-related lesions (one ASC-US, one LSIL, one ASC-H, and three HSIL), and 7 had anal HPV-related lesions (4 ASC-US, 2LSIL, and 1ASC-H).

\section{DISCUSSION}

Several studies have consistently reported a high prevalence and incidence of anal and cervical HPV infections in HIV-positive women and that the majority of anal HPV infections resolved within 3 years (MOSCICKI et al., 2010; PALEFSKY, 2009).

The results of the present study revealed high positivity for anal HPV (72.88\%), which is higher than the 43\% reported in a cross-sectional study conducted by Goeieman et al. of 200 HIV-infected women (GOEIEMAN et al., 2017).

Hessol et al. (2009) observed that women who engaged in anal intercourse were 3.8 times more likely to develop anal intraepithelial neoplasia, regardless of their immune status (HESSOL et al., 2009). However, no such association was noted, since only $18.6 \%$ of women who had positive anal HPV have reported unprotected receptive anal intercourse in the present study.

Anogenital HPV infection is often multicentric (HESSOL et al., 2009). A study conducted by Volpini et al. (2017) included 126 HIV-positive women and reported a high frequency of cervical and anal HPV infections in those with negative cytology and a $38.9 \%$ incidence of concomitant infection (VOLPINI et al., 2017). The plausibility that the cervix acts as a source of anal HPV infection is increased by the anatomical proximity of the vaginal introitus to the anus, but the likelihood that anal infection acts as a source of cervical infection is somewhat less (BUCCHI et al., 2016). However, the prevalence of anal infection seems to be higher than that of cervical infection. In the present study, the incidence of cervical HPV infection was $35.21 \%$, almost half of that of anal infection.

As a mechanism for the introduction of HPV into the anal canal in high-risk women, Simpson et al. (2016) suggested that front-to-back wiping was associated with a significant increase in the prevalence of HPV carriage/ co-carriage (SIMPSON et al., 2016).

There is a dearth of studies documenting the incidence of simultaneous cervical and anal dysplasia (BISHERWAL et al., 2016). For instance, Slama et al. (2015) who tested HPV at both sites noted concurrent anal and cervical HPV in $42 \%$ of women with a history of cytologically highgrade lesions (SLAMA et al., 2015). Comparatively, the results of the present study showed that the concurrency of HPV-related lesions was 30\%, mostly represented by ASC-US at both sites.
The progression of metaplasia to dysplasia and subsequently to neoplasia is a logical sequence and well-established as the genesis of cervical carcinomas. In the transformation zone, there is a transition from columnar epithelium to squamous epithelium through the process of squamous metaplasia, which is a reversible adaptive change in which one differentiated cell type is replaced by another that is better able to tolerate the adverse environment. If the condition promoting metaplasia persists, metaplasia can progress to dysplasia and occasionally to malignancy (ASSARZADEGAN; SOLANO, 2015; GIROUX; RUSTGI, 2017; WANG; SPARANO; PALEFSKY, 2017).

Our results showed an anal HPV/anal HPV-related lesion ratio of 4.3 and cervical HPV/cervical HPV-related lesion ratio of 2.5, indicating that despite a higher incidence of anal HPV, the progression to HPV-related lesion does not occur via the same manner in the cervix and anus.

Cervical metaplasia often exists in a dynamic state due to hormone stimulation (SOARES et al., 2019). However, this does not occur in the anal epithelium, which may explain why the development of HPV-related lesions is more likely in the cervix than in other sites.

In addition to active cervical metaplasia, anatomical differences may be responsible for this diversity in the infectious capabilities of HPV. Although the anorectal junction is presumably a squamocolumnar junction similar to that of the cervix, comparative microanatomy of the transition zones showed distinct topographic differences that may influence progression to anal cancer (YANG et al., 2015). In contrast to the single-layered columnar cells covering the basal cells of the cervical transformation zone, the anal transformation zone is lined by a multilayer of columnar cells (CLAVERO et al., 2017).

The American Cancer Society has proposed that women with a history of cervical or vulvar carcinoma benefit from anal cancer screening (BREGAR et al., 2018). In the present study, 100\% of women with HPV-related cervical lesions were positive for anal HPV, which reinforces the risk of anal HPV acquisition in this group of patients. Although inaccurate as the effect on the target population (HIV positive women), given that no confident intervals could be established, a clinically significant effect cannot be ruled out.

The limitations of this study are related to the cross-sectional design and the relatively small sample size. As HPV infections are transient, we may have overestimated the number of women with HPV infections at some time points. Nonetheless, future prospective studies with longer follow-up periods and larger sample sizes could justify the applicability of these data in larger populations.

\section{CONCLUSION}

Cervical HPV-related lesions in HIV-positive women may serve as cue for anal preventive strategies. Although there are differences in the susceptibility to HPV infections between the cervix and anus, with higher prevalence noted in the anus, further investigations of anal HPV in- 
fection of HIV-positive women with HPV-related lesions may be useful for screening of cervical cancer.

\section{REFERENCES}

ASSARZADEGAN, N.; SOLANO, F.J. Squamous metaplasia in colorectal polyps. Pathol. lab. med., Hyderabad, v. 1, n. 1, p. 1-2, 2015. Disponível em: https://openventio.org/wp-content/uploads/2017/08/SquamousMetaplasia-in-Colorectal-Polyps-PLMOJ-1-101.pdf. Acesso em: 03 Ago. 2019.

BISHERWAL, K. et al. Evaluation of cervical and anal intraepithelial neoplasia in women attending a sexually transmitted infection clinic. Indian j. dermatol. venereol. leprol., Mumbai, v. 82, n. 5, p. 498-504, 2016. Disponível em: http://www.ijdvl.com/article.asp?issn=03786323 ; year $=2016$; volume $=82 ;$ issue $=5 ;$ spage $=498$; epage $=504$; aulast $=\mathrm{Bi}$ sherwal. Acesso em: 03 Ago. 2019.

BREGAR, A. J. et al. Anal and Cervical High-Risk Human Papillomavirus Genotyping in Women With and Without Genital Neoplasia. J. lower gen. tract dis., Malden, v. 22, n. 2, p. 115-119, 2018. Disponível em: https:// journals.Iww.com/jlgtd/Abstract/2018/04000/Anal_and_Cervical_High_ Risk_Human_Papillomavirus.6.aspx. Acesso em: 19 oct. 2019

BUCCHI, D. et al. Human papillomavirus and gastrointestinal cancer: A review. World j. gastroenterol., Pleasanton, v. 22, n. 33, p. 7415-7430, 2016. Disponível em: https://www.ncbi.nlm.nih.gov/pmc/articles/ PMC5011658/pdf/WJG-22-7415.pdf. Acesso em: 03 Ago. 2019.

CLAVERO, O. et al. Squamous intraepithelial lesions of the anal squamocolumnar junction: histopathological classification and HPV genotyping. Papillomavirus res., Amsterdam, v. 3, n. 1, p. 11-17, 2017. Disponível em https://www.ncbi.nlm.nih.gov/pmc/articles/ PMC5883205/. Acesso em: 03 Ago. 2019.

CLEMENTE, N. et al. Multiple preinvasive and invasive HPV-related lesions of the anogenital tract in a female patient with HIV infection. Medicine (Baltimore), Hagerstown, v. 96, n. 4, p. e5948, 2017. Disponível em: https://www.ncbi.nlm.nih.gov/pmc/articles/PMC5287963/. Acesso em: 15 Oct. 2019.

DAVIS, K. G.; ORANGIO, G.R. Basic science, epidemiology, and screening for anal intraepithelial neoplasia and its relationship to anal squamous cell cancer. Clin. colon rectal surg., New York, v.31, n. 6, p. 368-78, 2018. Disponível em: https://www.ncbi.nlm.nih.gov/pmc/articles/ PMC6214809/. Acesso em: 15 Oct. 2019.

FRAZIER, E. L. et al. Screening for cervical cancer and sexually transmitted diseases among HIV-infected women. J. womens health (Larchmt), New York, v. 25, n. 2, p. 124-132. 2016. Disponível em: https://www.ncbi. nlm.nih.gov/pmc/articles/PMC5564184/pdf/nihms834992.pdf. Acesso em: 15 Oct. 2019.

GIROUX, V.; RUSTGI, A. K. Metaplasia: tissue injury adaptation and a precursor to the dysplasia-cancer sequence. Nat. rev. cancer, London, England, v. 17, n. 10, p. 594-604, 2017. Disponível em: https://www. ncbi.nlm.nih.gov/pmc/articles/PMC5998678/. Acesso em: 15 Oct. 2019

GOEIEMAN, B. J. et al. Prevalence of Anal HPV and Anal Dysplasia in HIVInfected Women From Johannesburg, South Africa. J. acquir. immune defic. syndr., New York, v. 75, n. 3, p. 59-64, 2017. Disponível em: https:// www.ncbi.nlm.nih.gov/pmc/articles/PMC5472492/pdf/nihms846812. pdf. Acesso em: 19 Oct. 2019

HESSOL, N. A. et al. Anal intraepithelial neoplasia in a multisite study of HIV-infected and high-risk HIV-uninfected women. AIDS, London, v. 23, n. 1, p. 59-70, 2009. Disponível em: https://www.ncbi.nlm.nih.gov/pmc/ articles/PMC2614220/pdf/nihms-84186.pdf. Acesso em: 9 Ago. 2019.

HIDALGO-TENORIO, C. et al. High prevalence and incidence of HPVrelated anal cancer precursor lesions in HIV-positive women in the late
HAART era. Enferm. infecc. microbiol.. clín., Barcelona, v. 36, n. 9, p. 555-562, 2018.

HUSMAN, A. M. R. et al. The use of general primers GP5 and GP6 elongated at their $3^{\prime}$ ends with adjacent highly conserved sequences improves human papillomavirus detection by PCR. J. gen. virol., England, v. 76, n. 4, p. 1057-1062, Apr.1995.

KLUMB, E. M. et al. Are women with lupus at higher risk of HPV infection? Lupus, London, v. 19, n. 13, p. 1485-1491, 2010.

LIN, C. et al. Cervical determinants of anal HPV infection and high-grade anal lesions in women: a collaborative pooled analysis. Lancet infect. dis., New York, v. 19, n. 8, p.880-891, 2019. Disponível em: https:// www.ncbi.nlm.nih.gov/pmc/articles/PMC6656696/. Acesso em: 9 Ago. 2019.

MACHALEK, D. A. et al. Anal human papillomavirus infection and associated neoplastic lesions in men who have sex with men: a systematic review and meta-analysis. Lancet. oncol., London, v. 13, n.5 p.487-500, 2012. DOI: 10.1016/S1470-2045(12)70080-3.

MANOS, M. M. et al. Use of polymerase chain reaction amplification for the detection of genital human papillomaviruses. Cancer cells, New York, v. 7, p. 209-214, 1989.

MOSCICKI, A. et al. Natural history of anal human papillomavirus infection in heterosexual women and risks associated with persistence. Clin. infect. dis., Chicago, v. 58, n. 6, p. 804-811, 2014. Disponível em: https://www.ncbi.nlm.nih.gov/pmc/articles/PMC3935503/pdf/cit947. pdf. Acesso em: 9 Ago. 2019.

PALEFSKY, J. Human papillomavirus-related disease in people with HIV. Current opinion in HIV and AIDS, Hagerstown, v. 4, n. 1, p. 52-56, 2009. Disponível em: https://www.ncbi.nlm.nih.gov/pmc/articles/ PMC2756707/pdf/nihms94538.pdf. Acesso em: 9 Ago. 2019.

SLAMA, J. et al. Impact of risk factors on prevalence of anal HPV infection in women with simultaneous cervical lesion. Neoplasma, Bratislava, $v$. 62, n. 2, p. 308-314, 2015.

SIMPSON S. J. et al. Front-to-back \& dabbing wiping behaviour posttoilet associated with anal neoplasia \& HR-HPV carriage in women with previous HPV-mediated gynaecological neoplasia. Cancer epidemiol., Amsterdan, v. 42 p. 124-32, 2016.

SOARES, L. C. et al. Association of Sexually Transmitted Diseases with Cervical Ectopy: A Systematic Review. Sex. transm. dis., Philadelphia, v. 46, n. 7, p. 452-457, 2019.

VOLPINI, L. P. B. et al. The high prevalence of HPV and HPV16 European variants in cervical and anal samples of HIV-seropositive women with normal Pap test results. Plos ONE, San Francisco, v. 12, n. 4, p. 176422, 2017. Disponível em: https://www.ncbi.nlm.nih.gov/pmc/articles/ PMC5398673/pdf/pone.0176422.pdf. Acesso em: 3 Ago. 2019.

WANG, C. J.; SPARANO, J.; PALEFSKY, J. M. Human immunodeficiency virus/AIDS, human papillomavirus, and anal cancer. Surg. oncol. clin. N. Am., Philadelphia, v. 26, n.1, p. 17-31, 2017. Disponível em: https://www. ncbi.nlm.nih.gov/pmc/articles/PMC5331942/. Acesso em: 3 Ago. 2019

YANG, E. J. et al. Microanatomy of the cervical and anorectal squamocolumnar junctions: a proposed model for anatomical differences in HPV-related cancer risk. Modern pathol., Baltimore, v. 28, n. 7, p. 994-1000, 2015. Disponível em: https://www.ncbi.nlm.nih. gov/pmc/articles/PMC4490106/pdf/nihms671670.pdf. Acesso em: 19 Oct. 2019.

Submetido em: 05/02/2021

Aceito em: 22/03/2021 